\title{
NEPENTHES FLAVA, A NEW SPECIES OF NEPENTHACEAE FROM THE NORTHERN PART OF SUMATRA
}

\author{
ANDREAS WISTUBA ${ }^{1}$, JOACHIM NERZ $^{2} \&$ ANDREAS FLEISCHMANN ${ }^{3}$
}

\begin{abstract}
SUMMARY
Nepenthes flava Wistuba, Nerz \& A. Fleischm. is described as a new species from northern Sumatra. It is described and illustrated, including a comparison with the supposed relatives $N$.inermis Danser, $N$. ovata Nerz \& Wistuba and N. jacquelineae C. Clarke, Troy Davis \& Tamin.
\end{abstract}

Key words: Nepenthes, Sumatra, carnivorous plants.

\section{INTRODUCTION}

In terms of the number of known Nepenthes species the flora of Sumatra is one of the richest in the world. In recent years several new species have been discovered and described, such as Nepenthes adnata Tamin \& Hotta ex Schlauer, N. angasanensis R. Maulder, D. Schub., B. Salmon \& B. Quinn, N. aristolochioides Jebb \& Cheek, $N$. diatas Jebb \& Cheek, N. lavicola Wistuba \& Rischer, N. longifolia Nerz \& Wistuba, N. mikei B. Salmon \& R. Maulder, N. tenuis Nerz \& Wistuba, N. jacquelineae and N. xiphioides B. Salmon \& R. Maulder (Nerz \& Wistuba, 1994; Jebb \& Cheek, 1997; Clarke, 2001). The number of known Sumatran species is even higher than the number of Bornean species, thus Sumatra certainly can be called a hotspot of evolution of Nepenthaceae. It can be assumed that some members of Nepenthes may have evolved quite recently; many species like $N$. singalana Becc. and $N$. bongso Korth. are quite variable and are closely related to each other. Some of the species however have very distinct and unique characteristics, such as e.g. the rimless $N$. inermis or the recently discovered $N$. jacquelineae with its monstrous peristome (Clarke, 2001). A new species of Nepenthes that had been discovered on a mountain in northern Sumatra is now described from cultivated material.

Nepenthes flava Wistuba, Nerz \& A. Fleischm., spec. nov. - Fig.1

Folia mediocria, lamina lanceolata-spatulata, nervis longitudinalibus 3 , vagina caulis $1 / 2$ amplectente. Ascidia rosularum ovate infundibuliformia, alis 2 fimbriatis; peristomio operculum versus acuminato 8-10 $\mathrm{mm}$ lato. Operculo anguste ovato; facie inferiore

1) Author for correspondence: andreas.wistuba@t-online.de; address: Mudauer Ring 227, 68259 Mannheim, Germany.

2) Arndtstraße 2, 71032 Böblingen, Germany.

3) LMU München, Department Biology I, Biodiversity Research, Systematic Botany and Mycology, Menzingerstrasse 67, 80638 Munich, Germany. 
carinata. Ascidia superiora mediocria, parte inferiore tubulosa, supra infundibuliformes, ore expanso, peristomio operculum versus acuminato 5-15 $\mathrm{mm}$ lato, margine exteriore expanso et undulato. Inflorescentia racemosa, pedicellis 4-11 mm longis omnibus 1-floris. - Typus: Wistuba cult. Wistuba 100201 (holo L; iso L), Northern Sumatra, 1800 m, material from a specimen in cultivation.

The plants grow as basal rosette only for a short time and start climbing early. Climbing plants reach several metres in height.

Stem almost round in cross section, c. $3 \mathrm{~mm}$ diam., green to dark red, internodes 2-14 $\mathrm{cm}$ long, glabrous, only young developing parts sparsely covered by red-brown basally branched hairs $0.2-0.5 \mathrm{~mm}$ long. Leaves oblong to narrowly obovate, $7-9$ by $1.5-2.5$ $\mathrm{cm}$, yellowish green, with glabrous margins; lamina with three prominent longitudinal nerves and indistinct reticulate nerves. The leaf-base clasps $1 / 2$ to $3 / 4$ of the perimeter of the stem. Tendrils $18-24 \mathrm{~cm}$ long, with curl, widely curved near the pitcher; young developing pitchers and tendril tips densely covered by red-brown hairs $0.5-1 \mathrm{~mm}$ long. Pitchers dimorphic, yellow to yellowish green in colour, rarely reddish, never spotted, peristome cream to light yellow, rarely red, occasionally with a few red stripes. Lower pitchers ovate-infundibulate , 4-7 by 3-4 cm, with two fringed wings in the upper third of the pitcher, the wings $2-3 \mathrm{~mm}$ wide with filiform fringes c. $5 \mathrm{~mm}$ long; peristome cylindrical to slightly expanded, folded or crenellated on the outer edge, $8-10 \mathrm{~mm}$ wide and finely ribbed, the ribs $0.1-0.2 \mathrm{~mm}$ apart; pitcher mouth round, slightly elongated to the back without a neck, or at most with just a slightly developed one; lid 2.5-3.5 by $1.5-2 \mathrm{~cm}$, narrowly ovate, elongated to linear with a glandular crest at the base of the lower surface; spur unbranched, filiform, 3-4 mm long; nectar glands circular, $0.3 \mathrm{~mm}$ diam., scattered over the lower surface of the lid, but concentrated around the midrib and glandular crest. Upper pitchers tubular in the lower part, infundibulate in the upper part; pitchers originate abruptly from the hanging end of the tendril; peristome flattened, partially expanded, 5-15 mm wide at both sides of the pitcher, outer margin distinctly crumpled, finely ribbed, the ribs $0.1-0.3 \mathrm{~mm}$ apart; lid elongated, ovate-cordate to linear, slightly truncate at the apex, $3-4$ by $1.8-2.5 \mathrm{~cm}$, bearing a slightly developed crest at the base; spur unbranched, filiform, 3-4 mm long; nectar glands circular, 0.3 mm diam., scattered over the lower surface of the lid, concentrated around the midrib and glandular crest. Male inflorescence 6-7 cm long, racemose, with 15-40 flowers; peduncle 3-4 cm long; pedicels 1-flowered, 4-6 mm long, usually with a basal bract of 2-3 mm length; tepals ovate, $2-3$ by $1 \mathrm{~mm}$, with nectar glands, tepal margins densely covered with short, curved red-brown hairs c. $0.2 \mathrm{~mm}$ long; androphore $3 \mathrm{~mm}$ long, anther head 1-1.5 mm diameter. All parts of the inflorescence yellow and covered by yellowish brown, short, branched hairs $0.5-1 \mathrm{~mm}$ long. Female inflorescence $6-7 \mathrm{~cm}$ long, racemose, with 15-25 flowers; peduncle 5-8 cm long; pedicels 1-flowered, 8-11 $\mathrm{mm}$ long, usually with a basal bract of 3-4 mm length; tepals ovate, $2-3$ by $1 \mathrm{~mm}$, with nectar glands, tepal margins densely covered with short, curved red-brown hairs c. $0.2 \mathrm{~mm}$ long; ovary 3-4 mm long, densely covered by red-brown hairs $0.5-1 \mathrm{~mm}$ long. All parts of the inflorescence yellow and covered by yellowish brown, short, branched hairs $0.5-1 \mathrm{~mm}$ long. Fruit and seed not seen.

Distribution - Northern Sumatra highlands (exact locality withheld for conservation purposes). 


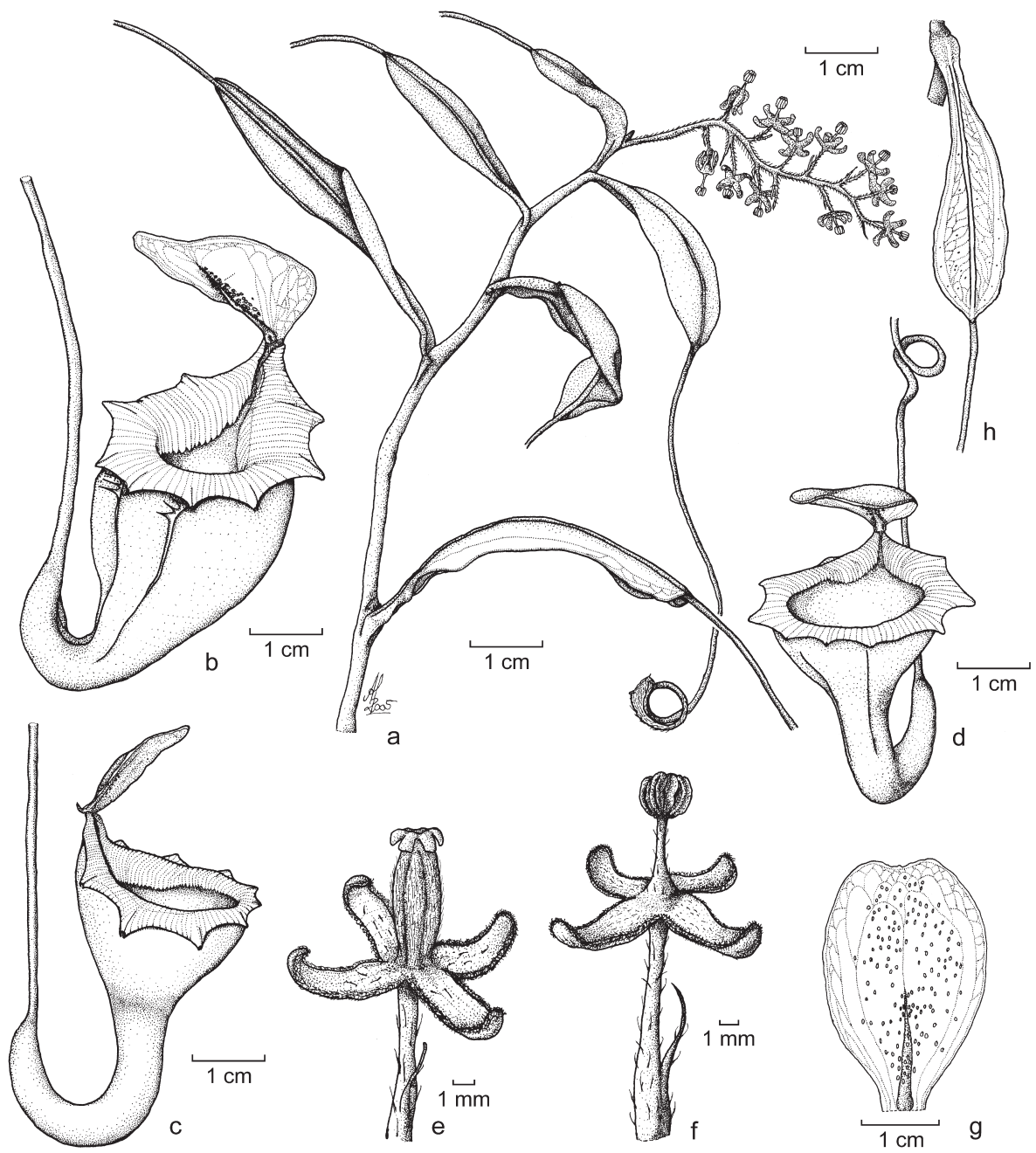

Fig. 1: Nepenthes flava Wistuba, Nerz \& A. Fleischm. a. Habit of male plant; b. lower pitcher; c. upper pitcher, lateral view; d. upper pitcher, frontal view; e. female flower; f. male flower; g. underside of lid; h. leaf venation pattern (Wistuba cult.).

Ecology - Terrestrial in montane forests, between 1800-2200 m above sea level. In more open parts of the Rhododendron-Leptospermum-forest, where the trees and shrubs typically do not exceed 4-5 $\mathrm{m}$ in height. Nepenthes flava grows together with N. mikei, N. ovata Nerz \& Wistuba, N. rhombicaulis Kurata and N. spectabilis Danser in this area.

Notes -1 . Hybrids: A few natural hybrids were observed, such as $N$.flava $\times$ ovata and $N$.flava $\times$ rhombicaulis. Most of the hybrids however were juvenile plants still in the rosette stage. No hybrids with N. mikei or N. spectabilis were observed. 


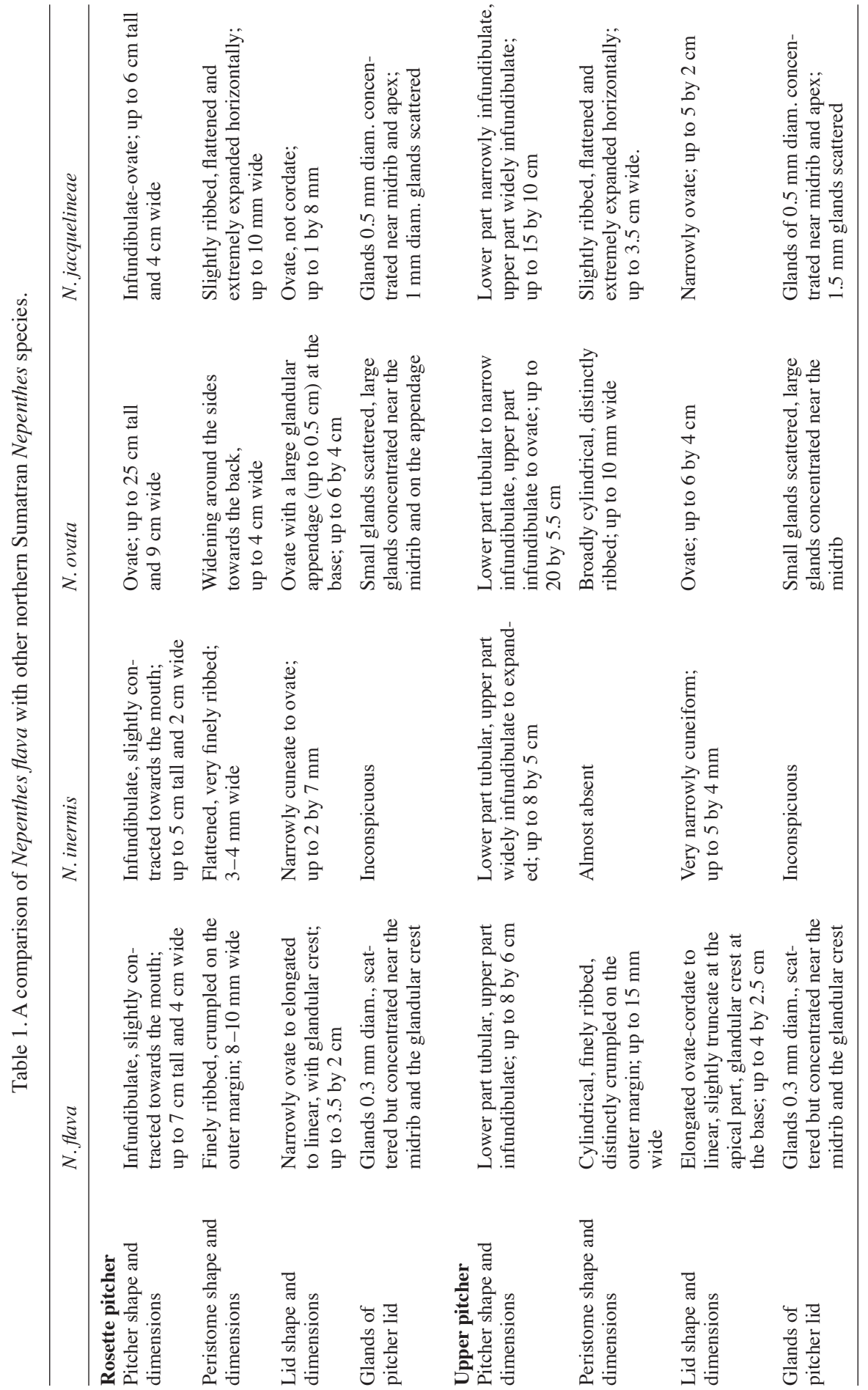


2. Concerning its affinity, $N$. flava is a very interesting species. It appears to be a link between common Sumatran species such as $N$. ovata, and two outstanding species $-N$. inermis and $N$.jacquelineae. Nepenthes flava shares many characteristics with $N$. inermis, such as infundibulate pitchers, the narrow lid, and the tendency to grow straight upwards with long internodes and short leaves in the juvenile state. The pitchers of seedlings of $N$. flava somewhat resemble those of $N$. inermis. Nepenthes flava also shows similarities to $N$. jacquelineae, such as its infundibulate lower and upper pitchers, a well-developed rim, and the narrow lid. Nepenthes flava might represent an intermediate between N. ovata of northern Sumatra and the unusual N. inermis of the western Sumatran mountains, and would confirm Danser's hypothesis in which he united common species familiar to him, i.e. N. bongso, $N$. carunculata Danser and $N$. singalana, with the distinctive species $N$. inermis and $N$. dubia Danser into the subgenus Montanae Danser (Danser, 1928). Nepenthes ovata, N. jacquelineae and others were not known at this time, but it seems likely he would have included them in subgenus Montanae as well.

3. Etymology: The specific epithet 'flava' refers to the bright yellow colour of the upper pitchers and most of the lower pitchers. Climbing plants especially give the impression of a mainly yellow plant.

4. Table 1 gives an overview of the differences between $N$. flava and three related species of northern Sumatra.

Specimens examined:

Wistuba 100201 (L), female plant with flowers, N Sumatra, 1800 m: holotype. Wistuba 100202 (L), male plant with flowers, N Sumatra, $1800 \mathrm{~m}$. Wistuba 100203 (L), rosetted plant, sterile, N Sumatra, $1800 \mathrm{~m}$. Wistuba 100204 (L), sterile, N Sumatra, 1800 m. Wistuba 100205 (M), rosetted plant, sterile, N Sumatra, $1800 \mathrm{~m}$.

\section{REFERENCES}

Clarke, C. 2001. Nepenthes of Sumatra and Peninsular Malaysia. Natural History Publications (Borneo), Kota Kinabalu.

Danser, B.H. 1928. The Nepenthaceae of the Netherlands Indies. Bull. Jard. Bot. Buitenzorg III, 9: $3-4$.

Jebb, M. \& M. Cheek. 1997. A skeletal revision of Nepenthes (Nepenthaceae). Blumea 42: 1-106.

Nerz, J. \& A. Wistuba. 1994. Five new taxa of Nepenthes (Nepenthaceae) from North and West Sumatra. Carniv. Pl. Newsl. 23: 101-114. 